\title{
Specificity of social existence in megalopolis
}

\author{
Svitlana Kutsepal $^{1}$, Natalia Zinchenko ${ }^{2}$, and Yulia Perebyynis ${ }^{1}$ \\ ${ }^{1}$ Poltava Law Institute of Yaroslav the Wise National Law University, Poltava, Ukraine \\ ${ }^{2}$ Ukrainian Medical Stomatological Academy, Poltava, Ukraine
}

\begin{abstract}
The paper is aimed at carrying out the social and philosophical analysis of the factors that determine the specificity of being as a resident of the megalopolis. It proves that residents of the megalopolis are subjected to double pressure: first, they are pressurized by a crowd, part of which they are forced to be constantly, and secondly - by their own ambitions and desires. All this substantially complicates the possibilities of selfpresentation and self-affirmation of an individual. The thesis that traditional values are transformed or neglected in the chronotype of the megalopolis and the value of consumption becomes the only dominant is also argued.
\end{abstract}

Key words: megalopolis, individual, community, consumption, chronotype of megalopolis.

\section{Introduction}

The main feature of the 21 st century society is mass consumption of goods, services, information, ideas, etc. which is clearly manifested in the megalopolis where peculiar conditions of human existence, specific mentality, different from the mentality of residents of the town or village, are created. Traditional values and customs are transformed or neglected there. Spreading of technologies, fragmentation of life, loss of identification and value markers are becoming ontological modes for residents of the megalopolis. Problems of self-presentation and self-affirmation are updated and becoming more and more complicated due to the imbalance between self-esteem, the perception of their selfhood and reactions of others as their expectations and illusions are often split upon a rock of cold indifference and even hostility of the urban community.

\section{Aim}

The study is aimed at providing social and philosophical analysis of factors determining specific character of human existence in the megalopolis.

\section{Material and methods}

Study of the megalopolis phenomenon and outlining the factors determining the specificity of the human being in the megalopolis environment implies the use of a complex interdisciplinary approach. The systematic and complex methods are the main ones since they are used to look into human existence in the conditions of the megalopolis on the system level and in the interdependence. The dialectical method is also used in order to reveal the essence of antinomy of the being and existence of a person in the context of urban challenges; the comparative method - to determine the distinction between urban and rural types of identity, to distinguish features of the identity of an inhabitant of the megalopolis, to reveal the essence 
of urban spaces and sub-spaces that make a city-dweller accept certain norms and rules of conduct; the phenomenological method - to analyze the chronotopos of the city; the culturalanthropological method - to study the influence of the megalopolis on the formation of its inhabitants' identity; the use of the inductive and deductive research methods have allowed us to consider the megalopolis both as integrity, and at the same time, focus on particular segments of this integrity.

\section{Results and discussion}

Intensifying urban processes, rapid development of cities, in particular, megalopolises, and decrease in a number of rural populations result in transformational processes taking place in the modern world. According to S. Veselova, the city of the modern age was a city of embodied rationality, and the modern city is escaping definitions and becoming more irrational [1]. However, it is also not worth to assert categorically that the modern city is the top of the irrational, an element of gadgets and machinery.

According to Lucia Sa, who has investigated life in two megalopolises -Mexico City and São Paulo, the modern metropolis is "the symbol of our times", and life there epitomizes modernity itself [2]. The chronotype of the metropolis is significantly different from the chronotype of the village or town, where space is clearly delineated outside own plot of land, and time is measured by the flow rather than fluttering at a crazy speed. Whereas the cultural reality of the village or town is characterized by uniqueness and philosophical slowness of existence, the megalopolis accumulates economic, cultural, social, productive, educational and political potential which leads to significant transformations of urban residents' personality.

The megalopolis is a product of post-modernity, where the historical part has long become a symbolic capital which brings significant dividends as tourists often turn to it. Urban residents themselves are captured by the "circle pit" through ghostly and seductive attractions of the city, plunging into the waterfall of the temporary quirky modes of the present moment. They abandon traditions in favour of innovations and fashion, "freeze" in the present, forgetting about the past and not hoping for the future. "Here and now" is the creed of ordinary residents of the megalopolis, so classical forms of the identity are destroyed and the need to develop new forms of the identity is actualized.

Urban space has been "humanized" (R. Bart) and its structure is complex as the city is the space of crossing for the vast number of individuals (S.Milgram); the business, entertaining, licensing, trade, history, etc. can be considered its elements."Buildings and cities do not participate in the general circulation of material goods but the circulation of material goods itself takes place in cities and buildings" [44]. In the plurality of subspaces, urban residents can realize their personal priorities focused on higher education, mass media, advertising, finance, international exchange, trade, etc. At the same time, with its advantages and disadvantages, urban lifestyle often leaves no choice for its residents, imposing commonly accepted norms and standards of behaviour, turning its inhabitants into "urban pipsqueaks". A villager or town inhabitant is usually open to the environment and communication with fellow creatures, which you will not see in the city due to its residents' fixation on their own micro-locations.

The megalopolis, like any city, consists of areas, each of which has its dominant function, its special degree of freedom and normalization of behaviour which shape relations within the city space. In his book "Reason in the City of Difference. Pragmatism, Communicative Action and Contemporary Urbanism", G. Bridge divides the city into areas and loci, in which, depending on the architecture and style, their residents' identity and outlook are 
changing. Different urban areas also have their own subcultures with meeting places and certain communication rituals, a degree of commitment to tradition, a degree of openness and an overall accessibility of urban spaces. The author dwells on that "it is reasonable to assume that any innovatory speech acts will have to conform to a set of rational expectations, or a norm. There is good reason to believe that the norms that exist in new situations of interaction are in fact coordination of rational expectations. Some of them might have been attained via the big leap of focal points... In the modern metropolis the prevailing convention of interaction and communication is one of indifference, involving minimized and neutral exchange of information among strangers... Mutual suspicion and self-repression behind the mask of rationality make the modern city very unpromising ground either for the giving-off of innovative signals or their reception. People will not be open to such suggestions" [4]. In other words, inhabitants of the metropolis belong to different types and strata of culture which leads to a lack of common ground between them and does not even provide for the possibility of dialogue between residents who often manifest diametrically opposite values, so communication is possible only in the form of confrontation.

In sociology, typical social and existential crises of inhabitants of the megalopolis (loneliness, social insecurity, deviant behaviour, loss of bodily privacy, emotional burnout, closed communicative micro-groups, long "dialogue" with computer instead of real communication, crisis in gender relations, etc.) have long been identified and researched, which gives grounds to argue about an increased risk of loss of existential meaning of being and development of depression and suicidal attitudes among inhabitants of the megalopolis. An individual is lost in the kaleidoscope of identity changes, loses clear boundaries of awareness of reality. In the rapid whirlpool of indifference and self-sufficiency of the megalopolis, anonymity and indifference of interpersonal relationships, an individual resident's loneliness is particularly acute as others are captured by problems of their own survival and comfort, as the neighbourhood model in the megalopolis does not provide the level of empathy and co-ownership that is characteristic of the village or town."Existential escapism may be an extreme form of loneliness, which indicates the point of the semantic bifurcation which a person passes through before choosing to abandon the Other and find oneself in a situation of rejecting the world and oneself" [5].

Even though the megalopolis has a much higher level of comfort and a wider range of utilities, its population is not constant, as the city is constantly changing, growing and transforming itself. R. Florida divides urban residents into rooted and mobile, able to quickly change their place of residence, depending on the temporary circumstances. Moreover, he emphasizes that "the thing to remember is that when it comes to place, like most other important things in life, we can't have it all. There are real tradeoffs to be made. Many people who move for their careers will give up the joy of being near family and lifelong friends. Those of us who choose to stay close to family and friends may give up economic opportunity" [6].

Inhabitants of the megalopolis are forced to live at fast, exhausting pace, losing stability and constancy of existence, to remember about force majeure situations of natural and manmade disasters, social cataclysms, each day consuming significant flows of services and information provided both directly and indirectly - through advertising that captures all the visual space and causes consequent inhabitants' sensory and psychological reactions. Advertising forms standards of behaviour, determines actions and decisions of inhabitants of the megalopolis, influences political and economic preferences, creates a space of hyperreality of existence where meaning of real things and relations becomes meaningless being substituted by their replicas and simulacra. Analyzing a vast number of contemporary practices in her book "Megalopolis: Contemporary Cultural Sensibilities", C. Olalquiaga 
states that "avoiding a rationale for consumption based on functionality (that is on possible use), postmodernism sponsors consumption as an autonomous practice" [7]. Due to this, shopping becomes so widespread that it is determined by successful trade manipulations and thirst for consumption, which is stoked in the media in every possible way. It is even worth to mention the phenomenon of oniomania, i.e. an unbridled passion for the purchase of goods, often unnecessary and not relevant to finances. Inhabitants of the megalopolis are forced to choose between the two extremes - either consumer euphoria or consumer despair, the crux of the matter is the question of whether a person consumes to survive or lives to consume [8].

The city is a space for consumption of impressions, promotional products, social and political myths, gender, ethnical and national stereotypes, replication of values and meanings, the imposition of communication models that satisfy both exquisite tastes of elite gourmets and needs of mass consumers. It is in the city that commodification (transformation of material and cultural values into the subject of commodity relations) and tertiarization (distribution of the service industry, its dominance over the traditional industry of material goods production) are most clearly manifested.

The space of the megalopolis is full of various performances that can arise both spontaneously - quarrels in the queue or in urban transport, and be properly thought out and organized - rallies, protest or support actions, massive violations of the order, accompanied by violence, robbery or various holiday celebrations, etc. It results in the emergence of certain social communities which a person can enter both consciously, seeking self-realization, recognition, achievement of a certain goal and spontaneously, accidentally, simply being at that time and in that place. The megalopolis combines numerous communities of people, both conventional and occasional (situational).

"The city is a field of conflicts, a space in which the competition of projects and programs unfolds; ... a theatre of existing positions and ways of life that is a tragic theatre of history" [9]. Residents of the megalopolis rarely can live alone as they are constantly forced to be part of the crowd where their intimate space is lost which may lead to indifference, alienation and aggression as a compensatory response. It is also one of the reasons why residents of the megalopolis long to be fenced off from the crowd with the help of gadgets - headphones, players, mobile internet, etc. - to show a visual disregard for others. An individual tries to protect and preserve the inviolability of the most mysterious part of the self, their axiological capital, their inner subjective sacredness.

Unlike the village or town, where the economic, social, financial, living conditions of inhabitants are quite modest, in the conditions of the megalopolis, the contrast between poverty and wealth is strikingly distinguished. There is a gradation of rich and poor areas, corruption is more aggressive. Unemployment, ethnic and multicultural conflicts, as well as a much higher crime rate are also realities of the city.

It is the level of crime that makes inhabitants of the megalopolis worry about the security and inviolability of their property as here people no longer feel that their home is their castle. Whereas in the village or town, home is perceived by a person primarily as a comfort zone, in urban conditions, it becomes an object of trouble and anxiety. Therefore, urban residents sometimes have to look at the world from the window of their own home through the grid, and manufacturers of protective equipment and security guards are never left without earnings.

The megalopolis attracts migrants: both rural people who traditionally seek to get to the city in search of better luck and material benefits and migrants from other countries, refugees, displaced residents, etc. Due to migration flows, the population of the metropolis increases and a large number of non-adapted marginal people are forced to fight for survival, 
which results in unemployment and social outbreak, as well as the criminalization of cities. "In the megalopolis, all elements of sociality are gathered, but the ease of interaction generates indifference and apathy in a person through acceleration and intensification of all social processes" [10]. The system of social control is weakened, loses stability; family relationships, friendly and partnership interactions respectively change.

The value of communication becomes obsolete as it is often either utilitarian or aggressive and even rash; meaningful and rich communication that can still be found in the town and village, where residents have been familiar for generations, is transformed into a fleeting, fragmentary, exchange of "smiles" and SMS with the most necessary messages. Communication of inhabitants of the city is a set of polylogue and dialogue discourses, situational disputes and conflicts, empathy, etiquette or speech aggression. An extremely extensive communication system, the constant presence of various types of mass media, performances having manipulative influence and propaganda, movement of the crowd, which can quickly transform both into the public and into the spontaneous combination of onlookers, - therefore here an individual finds oneself in the atmosphere of a living mosaic structure [11].

In the megalopolis, a peculiar social and psychological type of inhabitants is formed which is distinguished with rationality, readiness for constant changes of life circumstances, ability to coordinate their own interests with interests of other people, ability to cope with the complexity of the urban environment [12]. At the same time, inhabitants of the megalopolis are characterized by specific experiences, various fears (fear of accident, arriving late at work or lose it, fear for safety of their own homes, for safety of children, etc.) which are generated by the city's mega-scale, impossibility of optical perception, noise background, temporal and spatial challenges, awareness of latent danger hidden by technical and transport vehicles especially during rush hours, unpredictability of street life. All this generates so-called city neuroses that can result in catastrophic consequences for an individual.

"The influence of cities on a person's social life means a little more than the proportions of the urban population; as the city is not only a place of residence and work of a modern person, but also a generating and managerial centre of economic, political and cultural life that has drawn the most distant communities of the world into its orbit and has united different regions, different people and different kinds of activities into a single space" [13]. However, tolerance to any manifestations of the otherness, more tolerant treatment of civil marriage, attention to disabled people and migrants, establishment of charitable organizations, development of the volunteer movement, homeless shelters, defending own freedom with simultaneous recognizing and accepting the freedom of others, ability to see any other individual as a person possessing the same rights and duties like oneself can be considered as certain advantages of the megalopolis. In the modern megalopolis lifestyle, people have more opportunities to meet their cultural, educational and creative needs.

\section{Conclusion}

The megalopolis is not a frozen phenomenon as the city lifestyle standards which were typical in the twentieth century are changing, respectively, transforming urban residents' outlook and aspirations.

Socio-philosophical analysis of the factors that determine the specifics of the human being in the megalopolis provides a deeper understanding of the essence of social, cultural, political processes occurring in the megalopolis, lays a methodological basis for both understanding the general social contexts of spatial megalopolitan existence and perceiving existentialistic experiences of those whose lives make sense in the megalopolis. 
We can consider the following factors to be those determining the specificity of existence in the megalopolis:

1) the mega-scale, the awareness of which gives rise to a variety of urban dwellers' phobia, imposes their explicit and latent dangers, substantially affects their mental and physiological state;

2) the domination of generally accepted norms and standards of behaviour, the lifestyle imposed by advertising and mass media which results in loss of individuality;

3 ) the fluidity of socio-economic institutions, innovations in virtually all spheres of life that lead to the state of existential uncertainty, transformation of the city dweller into "the person of the moment" seeking to receive everything at once, to be ahead of others in the constant marathon to success and recognition;

4) the priority of consumption and entertainment that results in a change in the scale of values, predominance of a minute of enjoyment over real feelings and emotions;

5) flows of information, services, and finance form the megalopolis inhabitants' view of world which has its social and cultural manifestations. Due to rapid development of the media and communication technologies, the most attractive conditions for wide communication in the public discourse are created in the megalopolis.

The megalopolis offers numerous options for self-realization of its residents, it creates zones of their physical and mental comfort as well as provides for their career, status and cultural development.

The megalopolis is a materialized form of social existence. It is a kind of a social space and simultaneously a social organism which lives and functions according to its own laws, creates a peculiar model of social existence.

Carrying out socio-philosophical analysis of the megalopolis phenomenon, revealing the laws of urban life, studying the dialectics of the individual and public in the context of the megalopolis, is activated by the problems of physical and spiritual survival of mankind.

\section{References}

[1] С. Б. Веселова, Город - Архитектура - Философия. (2006). Available at: http://anthropology.ru/ru/text/veselova-sb/gorod-arhitektura-filosofiya.

[2] L. Sa, Life in the Megalopolis: Mexico City and Sao Paulo, 192 (Routledge, London, New York, 2007)

[3] С Леш, Соціологія постмодернізму. 344 (Львів: Кальварія, 2003)

[4] G. Bridge, Reason in the City of Difference. Pragmatism, communicative action and contemporary urbanism, 189, (Routledge, London, New York, 2005)

[5] Д. Г. Литинская, Типы современного эскапизма и феномен экзистенциального эскапизма, Ярославский педагогический вестник, $\mathbf{1}$, 308-311 (2012)

[6] R. Florida, Who's Your City? How the Creative Economy Is Making Where to Live, the Most Important Decision of Your Life, 384 (BasicBooks, New York, 2008)

[7] C. Olalquiaga, Megalopolis: Contemporary Cultural Sensibilities, 112 (University of Minnesota Press, Minneapolis, 1992)

[8] Z. Bauman, Globalization: The Human Consequences, 136 (Columbia University Press, New York 1998)

[9] А. В. Шипилов, «Своч», «чужие» и другие, 568, (Москва: «Прогресс Традиция», 2008) 
[10] Ю.В. Болотова Людина і місто у вимірі сучасних екзістенційних викликів // Місто. Культура. Цивілізація: матеріали VI міжнар. наук.теорет. Інтернет-конф., Харків, квітень, 15-17 (2016)

[11] М. Препотенська, Інтегральна людина як надбання мегаполісу, Філософія науки: традицї та інновацї, 1, 134-142 (2013)

[12] A. Madanipour, Designing the city of reason: foundations and frameworks, 342 (Routledge, London, New York, 2007)

[13] Л. Вирт. Избранные работы по социологии: Сб. переводов / РАН ИНИОН. Центр социал. науч.-информ. исслед. Отд. социологии и социальной психологи, 244 (Москва, 2005) 